\title{
Contextualizing the transformed roles of the school librarian and library: A case study to inform LIS education
}

\author{
Mary Moen \\ Assistant Professor and Coordinator of the School Library Media program \\ University of Rhode Island \\ mary_moen@uri.edu
}

\section{Introduction and Statement of the Research Problem}

Accredited school library educator preparation programs are responsible to align their curriculum to the American Association of School Librarians Standards for the Initial Preparation of School Librarians (2010). These standards include Teaching for Learning, Literacy and Reading, Information and Knowledge, Advocacy and Leadership, and Program Management and Administration. To keep more current with the actualities of the profession, the AASL recently released new National School Library Standards for Students, School Librarians, and School Libraries (2018). In the document, the roles and responsibilities of school librarians have been reexamined. A challenge for school library educator preparation programs is keep up to date with the changes to ensure a curriculum that prepares graduates with the relevant knowledge and skills to be effective school librarians. This study will help LIS schools by examining the attributes of a high-quality school library program in practice.

\section{Literature Review}

The new standards reflect the expanded and transformed roles of the school librarian and school library that have occurred in the past decade of changing trends in education (AASL, 2018). Librarians are: redesigning spaces to better fit the needs of collaborative student-centered learning (Kompar, 2015; Martin, Westmoreland, \& Branyon, 2011); supporting STEM learning through coding, robotics, and circuitry activities (Killeen, 2015); creating video production and presentation spaces (Johnson, 2013); supporting 1:1 device initiatives by providing professional development to teachers on educational technology (Harvey, 2013; Johnston, 2012); taking the lead on digital citizenship instruction for students (Hay, 2015; Stout, 2017); providing focused instruction in media literacy (Gardner \& Mazzola, 2018, Little, 2018); and leading the way in the makerspace movement (Abram, 2015; Chao, 2016; Jacobson, 2017; Moorefield-Lang, 2015). These professional articles showcase the myriad ways school libraries are transforming.

There is also, however, a small body of research examining current manifestations of school librarianship. School Library Journal has surveyed the frequency of library makerspaces in schools (Jacobson, 2017). Other studies have explored the role of the school librarian in Response to Intervention programs (Robins \& Antrim, 2012), as technology integration specialists (Johnston, 2012; Wine, 2016), as collaborators (Montiel-Overall, 2008), as co- teachers of literacy (Reed, 2018), as instructional partner to enhance science (Subramaniam et al, 2015) and the perceptions of librarians and libraries of primary school students (Batool \& Webber, 2017). Educator preparation programs may benefit from a broader, more contextualized picture of the roles and responsibilities of a school librarian today. This case study of a school library program in a district that was recently awarded the 
prestigious AASL National School Library Program of the Year award is significant because the findings will inform LIS schools on how they could revise their educator preparation programs to better prepare students for success as a school librarian today.

\section{Methodology}

This case study research will 1) examine how a nationally recognized school district has re-defined the role and expectations of school librarians, school library programs, and school library facilities to better support student learning and 2) investigate how partnerships with the school district and other organizations support the school library media program.

Data was collected by: 1) semi-structured individual and group interviews of librarians, administrators, teachers, and other individuals who partner with the district to support the school library media program. 2) document analysis of curriculum, lessons, relevant websites, library resources, and application to the AASL NSLPY award; and 3) site visits to school libraries. The interviews were recorded and transcribed. Content data analysis of the interviews was completed. The documents, notes and photos from on-site visits were examined using the inductive content data analysis strategy.

\section{Preliminary findings}

Preliminary findings indicate that effective school librarians need to exceptional teachers who create cross disciplinary student-centered learning experiences. They must be reflective practitioners and comfortable with taking risks and using technology. They should have vision in not only creating physical spaces that are welcoming, organized, and fit the needs of the students in their school, but in providing access to school library resources outside of the library walls. They must be passionate about reading, love children, and lifelong learners. They are leaders in

in designing and supporting digital learning opportunities. School districts also play a role in elevating the school librarian as a contributor to school improvement goals, student learning, and the community by providing supports such as flexible schedules, funds, continuing education and mentorship program. A district library coordinator who leads school library curriculum design and district wide projects ensures consistent services and materials across all school libraries.

\section{Discussion}

The findings from this study inform what knowledge, skills, and dispositions are essential for school librarians. The traditional roles of teacher, information specialist, instructional partner, program administrator, and leader are still relevant however the need for specific dispositions in the people who enter the school library field such as being risk-takers, visionary, and creative are highly valued as well. The role of the school district in supporting school libraries and the community's perceptions of the school librarian strengthens the school library program. Ensuring every student has equitable access to high quality school library resources, curriculum, and instruction is also important. There are several limitations to this study that should be taken into consideration. One is that it is a case study of one district and therefore cannot be generalized to all school districts. The second is that the participants were recruited by the district library coordinator as exemplars of best practices and therefore the data may not include all viewpoints of the school community.

\section{Implications and conclusions}

School library educator preparation programs should not only be continually revising and updating their curriculum to better prepare students to be effective school librarians, they should be recruiting students who have the disposition to be successful school library leaders. LIS schools may also want to consider the benefits of collaborating with school districts and other like-minded organizations to continually strengthen and update their school library educator preparation programs. 


\section{References}

Abram, S. (Jan/Feb 2015). Real makerspaces in school libraries. Internet@Schools, 22(1), 10 - 11.

American Association of School Librarians. (2010). Standards for the initial preparation of school librarians. Retrieved

fromhttp://www.ala.org/aasl/sites/ala.org.aasl/files/content/aasleducation/schoollibrary/2010 s tandards_with_rubrics_and_statements_1-31-11.pdf

American Association of School Librarians. (2018). National school library standards for learners, school librarians, and school libraries. Chicago: American Library Association.

Batool, S.H. \& Webber, S. (2017). Conceptions of school libraries and the role of school librarians: findings from case studies of primary schools in Lahore. Information Research, 22(1), CoLIS paper 1606. Retrieved fromhttp://informationr.net.uri.idm.oclc.org/ir/22-1/colis/colis1606.html

Chao, T. (Aug 2016). Making goes districtwide. School Library Journal, 62(8), 14. Gardner, M., \& Mazzola, N. (2018). Fighting Fake News: Tools and Resources to Combat

Disinformation. Knowledge Quest, 47(1), 6-7.

Harvey II, C.A. (Nov/Dec 2013). The librarian's role in schoolwide professional development. Library Media Connection, $24-25$.

Hay, L. (2015). The evolution of the icentre model: Leading inquiry, digital citizenship, and innovation in schools. Teacher Librarian, 42(4), 15 - 19.

Jacobsen, L. (2017). Maker movement grows in K-12 with librarians leading the way, finds SLJ survey. School Library Journal. Retrieved fromhttps://www.slj.com/?detailStory=maker-movement-grows-k-12-librarians-leading-wayfinds-slj-survey

Johnson, D. (2013). Power up! The new school library. Educational Leadership, 71(21), 84-85. Johnston, M. P. (2012). School librarians as technology integration leaders: Enablers and barriers

to leadership enactment. School Library Research, 15, 1-33.

Killeen, E. B. (2015). Supporting STEM to Remain Relevant. Teacher Librarian, 43(2), 52.

Kompar, F. (2015). Re-imaging the school library: The learning commons and systemic reform.Teacher Librarian, 42(4), 20 - 24.

Little, H. B. (2018). Media Literacy: A Moving Target. Knowledge Quest, 47(1), 16-23.

Martin, A. M., Westmoreland, D. D., \& Branyon, A. (2011). New design considerations that transform the library into an indispensable learning environment. Teacher Librarian, 38(5), $15-20$.

Montiel-Overall, P. (2008). Teacher and librarian collaboration: A qualitative study. Library \& Information Science Research, 30, 145-155.

Moorefield-Lang, H. (2015). Change in the Making: Makerspaces and the Ever-Changing Landscape of Libraries. TechTrends: Linking Research and Practice to Improve Learning, 59(3), $107-112$.

Reed, K. N. (2018). School librarians as co-teachers of literacy: Librarian perceptions and knowledge in the context of the literacy instruction role. School Library Research, 21, 1 - 29.

Robins, J., \& Antrim, P. (2012). School librarians and response to intervention. School Library Research, 15, 1-16.

Stout, R. (2017). Simple Steps to Digital Citizenship. School Library Journal, 63(7), 15.

Subramaniam, M., Ahn, J., Waugh, A., Taylor, N.G., Druin, A., Fleischmann, K.R., \& Walsh, G. (2015). The role of the school librarian in enhancing science learning. Journal of Librarianship and Information Sciences, 47(1), 3-16. 
Wine, L. D. (2016). School librarians as technology leaders: An evolution in practice. Journal of Education for Library and Information Science, 57(2), 207-220.

\section{Biography}

Mary Moen is an Assistant Professor and Coordinator of the School Library Media program in the Graduate School of Library and Information Studies at the University of Rhode Island. 